\title{
GLOBAL, REGIONAL AND LOCAL SIMILARITIES AND DIFFERENCES IN HRM IN LIGHT OF CRANET RESEARCHES (2008-2016)
}

\author{
József Poór \\ J. Selye University, Komárno, Slovakia \\ Ildikó Éva Kovács \\ Szent István University, Gödöllö, Hungary \\ Karoliny Zsuzsa \\ University of Pécs, Hungary \\ Renata Machova \\ J. Selye University, Komárno, Slovakia
}

\begin{abstract}
In the research field of Human Resource Management (HRM) there has always been a need to explore and explain the similarities and differences in HRM practice of diverse countries. To do so, various national, cultural and institutional characteristics used to be considered by comparative HR research on HRM practices. The studies target not only whether country groups or regions can be detected with distinctive HRM characteristics, but also to search for the explanatory factors of it. Following contextual research paradigm, this paper is trying to find an answer for the question: what characteristic features the HRM practices of the formerly state-owned consequently centrally planned and controlled firms, since the 1990's operating in "new capitalism" of the Central and Eastern European countries show compared to the current global and regional tendencies? In doing so the study follows not only the theoretical approaches related to HRM, but also the conceptual framework provided by cultural clusters and comparative economics.
\end{abstract}

Keywords: Human Resource Management, Comparative International HRM, Central and Eastern Europe (CEE)

DOI: http://dx.doi.org/10.15549/jeecar.v6i1.253

\section{INTRODUCTION}

The relationship between socio-economic development and culture has been the focus of researchers for several decades. A need has been developed in the field of management research to find an explanation for the 
similarities and differences in management practices of different countries. The expansion of globalization has led to increasing demand for comparative research (Brewster, 2007); this tendency can also be observed in a special field of management sciences - the HRM. A debate over the theory and practice of comparative management - reflecting on the influence of globalization - evolved around the dilemma of convergence and divergence, with an emphasis that external contextual dependence of management occurs in various national environments (Brewster, 2004). There have been numerous explanations to promote the understanding of differences between the regions and countries, and a number of researchers have pointed out the correlations between culture and the behavioral patterns in the economy and economic performance (e.g. Bakacsi, 2008; Brodbeck, et al. 2000; Granell, 2000; Harrison, 1985; Inglehart \& Baker, 2000; Lands, 1998; North, 2005; Trompenaars \& Hampden-Turner, 1997). Since there are country and regional differences in human resource management, another important issue is, whether these differences are decreasing or increasing; and the increasing globalization of business life results in similarities or even more differences in HR practices of different regions (Brewster, 2004).

The CRANET research network, specializing in international $\mathrm{HR}$ research enables the identification of the European HRM trends (Brewster, et al., 2010). The worldwide network offers a comparative study of countries with different management cultures. Brewster (2007) points out that the large-scale representative data of CRANET surveys supports the dynamic nature of the evolving business systems. The CRANET research has also mentioned the concept of convergence (Brewster, 2004), differentiating the directional convergence (direction of change is similar in each country) and the final convergence (direction of change is different, but points towards the emergence of similar and universal practice) (Brewster, 2004). Undoubtedly, there are HR practices and features showing similar characteristics and/or direction of changes. These include the following, e.g.: relative decrease of the size of HR departments, increasing rate of performance-based pay or the increase of flexible patterns of employment (Brewster, 2007). Based on empirical studies we cannot talk about the final convergence of HR practices. In contrary to previous assumptions, the standardization of HR practices despite the globalization effect is not a self-evident process (Mayrhofer, et al., 2004). The attention of researchers is directed at seeking and interpreting differences and explanatory factors.

Following the political and economic transition of the 90s, many Central and Eastern European countries joined the CRANET network, which made it possible to explore and understand the HRM practices in the countries of the region., as Additionally, it provides the possibility to map the differences existing in the first decades of the $21^{\text {st }}$ century. Morley, at al. (2009) have pointed out that in comparison to other regions, the Central and Eastern European region can be characterized with significant structural, institutional and configuration differences, as well as significant differences which can be identified in HRM practices (Venegas, et al., 2017). The countries of the region can be characterized with lacking autonomy in HR practices. Following the political and economic transition, it is difficult to determine whether these countries really represent a new form of the capitalist economy (Brewster, et al., 2010).

\section{CONCEPTUAL FRAMEWORK}

The concept of convergence and divergence is not new to international HRM. The representatives of the Universalist approach (Hickson, et al., 1974; Kerr, et al., 1960) believe that technological development and competition will suppress cultural differences, and this creates convergence among the formerly different practice of the nations. The strengthening of globalization has increasingly accepted this theory in HR (Kelley, et al., 1995; Sparrow, et al., 1994). According to representatives of culture-free trend, the local/national culture is irrelevant for the application of various HRM/IHRM techniques. According to Mullins (2005), after the Second World War, for example, the American and Swedish companies tried to translate their own autonomous working group into other cultures, 
just as the Japanese did with their own management methods. These aspirations have, in varying degrees, succeeded. The leading advocates of this trend say, that companies are trying to follow the North American HRM model. As a result of their assumptions, the differences in HR practices are decreasing worldwide, and best practices as universal solutions will emerge.

The development of modern HRM theory and practice has long been equivalent with the development of HRM in the United States. According to development of the US-HRM, Brewster, et al. (2004) identified four influencing factors: the specific labor law environment, the liberal economic regulation system, the limited role of trade unions, and the low-context business culture. Theories and methods of the American HRM, undoubtedly had a major impact on the evolution of HR practice around the world (Boxall \& Purcell, 2003). However, usually individualistic models of HRM Anglo-Saxon, are often difficult to apply to a diverse cultural heritage and to different social, economic, institutional backgrounds in Europe or Asia, but even similarly difficult in the Anglo-Saxon Australia or New Zealand (Csillag, 2014).

Because of the above, the European HRM model is the American HRM concept, whose rhetoric has been criticized by many European authors (e.g. Brewster, 2007; Guest, 1990; Legge, 2005), and was developed in response to hegemony (Michailova, et al., 2009). The concept of the European model was founded by Brewster (1995). It is characterized by the recognition of the participation of the state and the trade unions in the regulation of employment, in contrast to American approaches. It is based on the basic principle of the German social-welfare state. Its decisive elements are solidarity and social cohesion, and interest reconciliation and strong state regulation play an important role, as well as do social dialogue and social responsibility (Armstrong \& Taylor, 2014). The European HRM has thus evolved from the field of labor relations, which has been transferred to HRM by the assumption of national embeddedness and awareness of national differences, thus facilitating the development of comparative
HRM (Brewster, 2007). The representatives of the contextual approach emphasize the existence of national, cultural and institutional differences and the survival of their influence. They claim that decrease in these differences can hardly be expected, so there is little chance for unification of HR practices. Representatives of this trend emphasize the importance of local culture, business ecosystems, the institutional environment and the labor market when applying management techniques (Brewster, 2004; Due, et al., 1991; Hofstede, 1980; Morley \& Collings, 2004; Ronen \& Shenkar, 1985). In Europe, Brewster (2004) not only showed significant differences between the US and European HR management systems, but also identified differences among several country groups or regions in Europe.

Brewster $(2004,2007)$ points out that besides the worldwide spread of the American model, others stand out for the regional models of HRM, and those, who say that due to growing political and economic integration of the EU countries, a clear convergence towards a European practice is emerging. In addition to the advocates of the American model spreading around the world, others stand up to the regional models of HRM, and there are those who believe that the increasing political and economic integration of the European Union countries is creating a convergence towards European HRM practice within EU. The Central and Eastern European region is particularly interesting, where the most important change in the past 25 years has been a shift from a focus on administrative services to more performance-oriented HR activity. The influx of working capital and management know-how and practices has had a significant impact on the activity of the region's organizations. HRM on the firm level has gained a significant importance since the 1990s. Consequently, the main questions of this paper are: What are the organizations of Central and Eastern Europe doing now in comparison to HRM practices of the industrialized countries? What are the characteristic features of the HR work in these countries?

As an explanatory factor for differences between the US and European solutions, more and more people mention and accept the 
findings on the diversity of market economies and the types of capitalism. To categorize the institutional systems of the capitalist countries, Hall and Soskice (2001) identified two types of capitalism that can be described with different characteristics: Liberal Market Economies (LME), members of the Anglo-Saxon countries (USA, Canada, UK, Australia, New Zealand) and the Coordinated Market Economies (CME) countries, which, in addition to Japan, are mainly listed as the continental Western European countries (Germany, Benelux, Switzerland, Denmark, Norway, Sweden, Austria).

Hall and Soskice (2001), in their later works, acknowledged the existence of other alternative models of capitalism. According to their views, the emerging market economies (EME), the Mediterranean or Mixed Market Economies (MME) and the emerging Central and Eastern European region (Hancke, et al., 2007; Amable, 2003) are worth examining.

Brewster (2007) also points out the relationship between comparative HRM and comparative economics (Hall \& Soskice, 2001; Hall \& Gingerich, 2004; Psychogios \& Wood, 2010). This is obvious when we consider that one of the fundamental questions is how the society treats the relationship between the employers and the employees; how it is handled; and HRM is one of the management functions that depends on the institutional setup and other factors closely linked to nation states. According to the institutional arrangements, the differentiation between the countries of North and South Europe (Amable, 2003; Hall \& Gingerich, 2004; Whitely, 1999) was extended to HRM (Brewster, 2007; Brewster, et al., 2010; Brewster \& Bennett, 2010; Poutsma, et al., 2006; Wood, et al., 2009), not least in the comparative international HRM research. The institutional arrangement of a country is not independent of culture and its decisive values, and it is indisputable that the two interpretations simply examine the same factors from different points of view, says Brewster (2004:376). Thus, it is not surprising that the grouping based on the explicit political, legal, economic environment and its institutional features is very similar to valuebased cultural considerations (Brodbeck, et al.,
2000; Gupta, et al., 2002; Hofstede, 1980; Inglehart \& Baker, 2000; Koopman, et al., 1999; Ronen \& Shenkar, 1985; Smith, et al., 1996).

\section{METHODOLOGY}

CRANET (Cranfield Network), the largest international, independent HRM research network, coordinated by Cranfield Business School, was established at the initiative of ILO in 1989 (Lazarova, et al., 2008). The focus of the founders was on concepts of comparative HRM and differences between the countries, committed to identifying the European HRM trends (Brewster, et al., 2010). The network of universities and research associates originally set up by five Western European universities has become global (Mayrhofer, 1998). Nowadays, it is connecting the researchers of about 40 countries and plays a prominent role in international development of HRM practices.

Our research is based on research data collected by the CRANET research network through a questionnaire survey with a focus to explore the similarities and differences of the HR policies and practices of specific country clusters, focusing on the characteristics of the CEE region. The authors of this article have been members of the international Cranet network for nearly two decades. Relying on their previous comparative research, global, regional and local similarities and differences of HRM were examined in their own research in the context of three Cranet surveys.

\section{Country Clusters}

Based on the results of different culture research (Brodbeck, et al., 2000; Gupta, et al., 2002; Hofstede, 1980; Inglehart \& Baker, 2000; Koopman, et al., 1999; Ronen \& Shenkar, 1985; Smith, et al., 1996) and comparative economics (Amable, 2003; Hall \& Soskice, 2001; Hall \& Gingerich, 2004; Psychogios \& Wood, 2010), on the basis of cultural and institutional characteristics, the European countries of the CRANET databases of this study use six clusters. The United States as a separate cluster is justified by differences in the American and European HRM practices (Brewster, 2004), although both the comparative economics and the culture research have shown that the 
United States and the United Kingdom belong to the same cluster (LME or Anglo-Saxon Country Group). In classification of Greece there is a contradiction between cultural research and comparative economics, so we considered it justified to include it as a separate cluster. Consequently, taking into account the countries participating in the CRANET survey, in some cases, each cluster is represented by only one country. Thus, the created clusters were as follows:

- USA (the United States of America)

- UK (the United Kingdom)

- GERMAN (Austria, Germany, Switzerland)

- NORTHERN (Norway, Sweden, Denmark, Finland)

- LATIN (France)
- CEE/Central and Eastern Europe (Estonia, Hungary, Lithuania, Slovakia, Slovenia, Serbia)

- EASTERN PERIPHERY (Greece)

Data about Hungary appears as a separate "cluster" in the analysis. (Comments: Since most of the authors live in this country, we considered it is useful to analyse data of a Hungarian cluster as well.) Only the countries involved in the CRANET survey of 2008-2010 and 2014-2016 were included in the sample. We analysed the responses, where the number of employees and the HR departments was indicated.

The results of the survey sample are presented in Table 1.

Table 1 . The number of organization of the surveyed country groups in CRANET survey of 2008/10 and $2014 / 16$

\begin{tabular}{|c|c|c|c|c|c|c|c|c|c|}
\hline Year & USA & UK & German & Northern & $\begin{array}{c}\text { Lati } \\
\mathbf{n}\end{array}$ & CEE & $\begin{array}{c}\text { Eastern } \\
\text { Periphery }\end{array}$ & Total & Hungary \\
\hline $\mathbf{2 0 0 8 / 1 0}$ & 448 & 202 & 704 & 856 & 145 & 805 & 214 & 3374 & 130 \\
\hline $\mathbf{2 0 1 4 / 1 6}$ & 465 & 296 & 717 & 926 & 157 & 1132 & 186 & 3879 & 268 \\
\hline
\end{tabular}

Source: Based on CRANET surveys of 2008/10 and 2014/16; Authors' own research

The questionnaires contained some of 400 variables describing HR functions (i.e. the size of the HR department, HR's strategic role, the role of trade unions, benchmarking, performancebased wages, flexible work contracts, atypical employment patterns). These were the factors we used to examine the role of HRM and its change in the regions described above. The further aspect of selecting variables was the ability to link them to HR areas and the ability to compare HRM practice of nations, regions, and track changes in time.

We were looking for the answers to the following questions:

- What kind of changes can be detected in HR practices of Central and Eastern Europe and Hungary? Are there converging trends in HRM practices of the region and
Hungary with the trends in the world's most economically advanced regions?

- Are Central and Eastern European characteristics and divergent features identified in the HR practice of our region (e.g. CEE) and the organizations of Hungary?

- Are the changes in Hungarian HRM practice similar to other countries in the region? Which areas are affected if the practices differ? Are there any specific features of Hungarian HRM practice?

Contextual features of organizations in the examined regions

The regional differences or similarities may arise from contextual features of the organizations involved in the survey. 
Table 2. Employee number in the surveyed country groups (\%)

\begin{tabular}{|c|c|c|c|c|c|c|c|c|c|c|c|c|c|c|c|c|c|c|}
\hline & \multicolumn{2}{|c|}{ USA } & \multicolumn{2}{|c|}{ UK } & \multicolumn{2}{|c|}{ German } & \multicolumn{2}{|c|}{ Northern } & \multicolumn{2}{|c|}{ Latin } & \multicolumn{2}{|c|}{ CEE } & \multicolumn{2}{|c|}{$\begin{array}{l}\text { Eastern } \\
\text { Periphery }\end{array}$} & \multicolumn{2}{|c|}{ Total } & \multicolumn{2}{|c|}{ Hungary } \\
\hline & 2010 & 2016 & 2010 & 2016 & 2010 & 2016 & 2010 & 2016 & 2010 & 2016 & 2010 & 2016 & 2010 & 2016 & 2010 & 2016 & 2010 & 2016 \\
\hline $\begin{array}{l}\text { Under } \\
250\end{array}$ & 44,0 & 22,8 & 44,1 & 35,8 & 25,0 & 16,6 & 28,3 & 30,7 & 24,8 & 21,0 & 58,8 & 56,3 & 30,8 & 39,8 & 37,9 & 35,0 & 64,6 & 51,5 \\
\hline $\begin{array}{l}251- \\
1000 \\
\end{array}$ & 19,6 & 36,1 & 36,1 & 29,7 & 39,9 & 50,5 & 44,5 & 42,3 & 57,2 & 35,7 & 28,0 & 29,5 & 41,6 & 38,7 & 36,2 & 37,9 & 19,2 & 29,5 \\
\hline $\begin{array}{l}1001- \\
5000\end{array}$ & 19,0 & 23,7 & 13,4 & 14,9 & 24,7 & 23,0 & 21,1 & 21,7 & 11,7 & 27,4 & 12,0 & 11,8 & 20,6 & 17,2 & 18,5 & 18,8 & 15,4 & 14,5 \\
\hline $\begin{array}{l}\text { Over } \\
5000\end{array}$ & 17,4 & 17,4 & 6,4 & 19,6 & 10,4 & 9,9 & 6,1 & 5,3 & 6,2 & 15,9 & 1,2 & 2,4 & 7,0 & 4,3 & 7,4 & 8,2 & 0,8 & 4,5 \\
\hline Total & 100,0 & 100,0 & 100,0 & 100,0 & 100,0 & 100,0 & 100,0 & 100,0 & 100,0 & 100,0 & 100,0 & 100,0 & 100,0 & 100,0 & 100,0 & 100,0 & 100,0 & 100,0 \\
\hline
\end{tabular}

Source: Based on CRANET surveys of 2008/10 and 2014/16; Authors' own research

The diverse role of the trade unions is treated as a priority in our study. The other aspect we were interested in, is whether the organization is profit-oriented, public or non-profit.

With respect to organizational size, characterized by number of employees, the distribution of the entire sample was similar in both survey periods (Table 2). The majority of organizations involved in the survey (74/73\%) have less than 1000 employees. The ratio of large companies with more than 1000 employees is below the sample average in Central and Eastern European countries, as the representation of these organizations is 13 and $14 \%$, while the Hungarian sample shows 16\% and $19 \%$.

Table 3. Categorization of the surveyed organizations based on sectors in the country groups (\%)

\begin{tabular}{|c|c|c|c|c|c|c|c|c|c|c|c|c|c|c|c|c|c|c|}
\hline & \multicolumn{2}{|c|}{ USA } & \multicolumn{2}{|c|}{ UK } & \multicolumn{2}{|c|}{ German } & \multicolumn{2}{|c|}{ Northern } & \multicolumn{2}{|c|}{ Latin } & \multirow{2}{*}{\begin{tabular}{|c|} 
CEE \\
2010 \\
\end{tabular}} & \multicolumn{3}{|c|}{ Eastern Periphery } & \multicolumn{2}{|c|}{ Total } & \multicolumn{2}{|c|}{ Hungary } \\
\hline & 2010 & 2016 & 2010 & 2016 & 2010 & 2016 & 2010 & 2016 & 2010 & 2016 & & 2016 & 2010 & 2016 & 2010 & 2016 & 2010 & 2016 \\
\hline $\begin{array}{l}\text { Privat } \\
\text { e }\end{array}$ & 40,9 & 41,4 & 64,0 & 78,0 & 76,3 & 73,7 & 61,4 & 55,2 & 97,9 & 92,8 & 76,7 & 70,8 & 92,0 & 85,6 & 69,8 & 66,8 & 70,5 & 64,1 \\
\hline Public & 40,7 & 37,3 & 16,9 & 6,6 & 13,2 & 11,8 & 34,2 & 36,5 & 1,4 & 3,9 & 19,0 & 26,7 & 5,5 & 12,2 & 22,4 & 24,2 & 21,7 & 32,4 \\
\hline Mixed & 0,5 & 3,0 & 6,6 & 3,3 & 2,7 & 7,1 & 2,5 & 4,8 & 0,0 & 1,3 & 3,1 & 1,1 & 1,0 & 2,2 & 2,5 & 3,5 & 6,2 & 0,4 \\
\hline $\begin{array}{l}\text { Non- } \\
\text { profit }\end{array}$ & 17,9 & 18,2 & 12,5 & 12,1 & 7,8 & 7,5 & 1,9 & 3,6 & 0,7 & 2,0 & 1,2 & 1,4 & 1,5 & 0,0 & 5,3 & 5,4 & $\overline{1,6}$ & 3,1 \\
\hline Total & 100,0 & 100,0 & 100,0 & 100,0 & 100,0 & 100,0 & 100,0 & 100,0 & 100 & 100,0 & 100,0 & 100,0 & 100,0 & 100,0 & 100,0 & 100,0 & 100,0 & 100,0 \\
\hline
\end{tabular}

Source: Based on CRANET surveys of 2008/10 and 2014/16; Authors' own research

According to the form of ownership, slightly more than two-thirds (70/67\%) of the businesses represented the private sector during both of the survey periods. Significant differences can be detected between the country groups. The ratio of businesses in the US private sector slightly exceeds the ratio of organizations in the public sector, as well as significant ratio is formed by non-profit organizations. In France (98/93\%) and Greece $(92 / 86 \%)$ the majority of businesses represent the private sector. In other country groups, including Hungary, the ratio of private sector businesses exceeds the public sector representatives (Table 3 ). 


\section{RESULTS}

\section{The role of trade unions}

The role of trade unions, as well as the power of their influence can have significant impact both on the practices and the effectiveness of HR functions. A bit more than a quarter of businesses had no union member in both periods, but each of the country groups show significant difference. As it was expected (Brewster, 1995, 2004), the USA has a largest number of companies with no union member (60\%), while the North European countries show the highest discipline regarding the question of trade unions (only $1 \%$ of the companies have no union member).

Table 4 . The role of trade unions in different country groups

\begin{tabular}{|c|c|c|c|c|c|c|c|c|c|c|}
\hline \multirow{3}{*}{$\begin{array}{l}\text { Country } \\
\text { groups }\end{array}$} & \multicolumn{5}{|c|}{$2008 / 2010$} & \multicolumn{5}{|c|}{$2014 / 2016$} \\
\hline & \multirow{2}{*}{$\begin{array}{l}\text { No } \\
\text { union } \\
\text { member } \\
(\%)\end{array}$} & \multirow{2}{*}{$\begin{array}{l}\text { No } \\
\text { influe } \\
\text { nce } \\
(\%)\end{array}$} & \multirow{2}{*}{$\begin{array}{l}\text { Not } \\
\text { recognized } \\
\text { for a } \\
\text { purpose of } \\
\text { collective } \\
\text { bargaining } \\
(\%) \\
\end{array}$} & \multicolumn{2}{|c|}{$\begin{array}{l}\text { The influence of } \\
\text { trade unions }\end{array}$} & \multirow{2}{*}{$\begin{array}{l}\text { No } \\
\text { union } \\
\text { membe } \\
\mathrm{r} \\
\text { (\%) }\end{array}$} & \multirow{2}{*}{$\begin{array}{l}\text { No } \\
\text { influe } \\
\text { nce } \\
(\%)\end{array}$} & \multirow{2}{*}{$\begin{array}{l}\text { Not } \\
\text { recognized } \\
\text { for a } \\
\text { purpose of } \\
\text { collective } \\
\text { bargaining } \\
(\%) \\
\end{array}$} & \multicolumn{2}{|c|}{$\begin{array}{l}\text { The influence of } \\
\text { trade unions }\end{array}$} \\
\hline & & & & $\begin{array}{l}\text { Avera } \\
\text { ge }\end{array}$ & $\begin{array}{l}\text { Standa } \\
\text { rd } \\
\text { deviati } \\
\text { on }\end{array}$ & & & & $\begin{array}{l}\text { Averag } \\
\text { e }\end{array}$ & $\begin{array}{l}\text { Standard } \\
\text { deviation }\end{array}$ \\
\hline USA & 65,8 & 63,2 & 67,8 & 0,74 & 1,123 & 59,9 & 39,3 & 37,4 & 1,38 & 1,422 \\
\hline UK & 35,5 & 45,3 & 51,0 & 1,20 & 1,316 & 45,2 & 69,9 & 72,8 & 0,43 & 0,755 \\
\hline Germanic & 20,4 & 32,8 & 0,0 & 1,21 & 1,088 & 17,5 & 34,2 & $19,3^{*}$ & 1,30 & 1,224 \\
\hline Northern & 0,5 & 8,2 & 12,8 & 2,09 & 1,026 & 1,1 & 8,1 & 6,3 & 2,25 & 1,098 \\
\hline Latin & 10,8 & 5,0 & 2,9 & 1,91 & 0,686 & 16,2 & 17,9 & 10,4 & 1,66 & 1,083 \\
\hline CEE & 45,7 & 42,1 & 41,8 & 1,05 & 1,064 & 37,1 & 52,3 & 49,3 & 1,01 & 1,309 \\
\hline $\begin{array}{l}\text { Eastern } \\
\text { Periphery }\end{array}$ & 34,6 & 32,1 & 19,9 & 1,30 & 1,160 & 36,5 & 46,1 & 42,3 & 0,98 & 1,122 \\
\hline Total & 28,7 & 31,7 & 25,6 & 1,38 & 1,176 & 26,9 & 36,1 & 31,8 & 1,39 & 1,319 \\
\hline Hungary & 59,3 & 59,2 & 29,3 & 0,72 & 0,974 & 50,5 & 67,0 & 67,8 & 0,56 & 0,941 \\
\hline
\end{tabular}

* The 2014/16 survey only contains the responses of the Austrian and Swiss companies, the responses of German companies are missing (probably due to data error)

Source: Based on CRANET surveys of 2008/10 and 2014/16; Authors' own research.

The 2008/2010 CRANET survey shows a dramatic decrease in the number of organized workers compared to the previous survey conducted in 2004/05 in the former socialist (CEE) countries. According to 2004/05 survey, there was no trade union member at all in 35\% of the Hungarian companies, 33\% of the Central and Eastern European companies and 20\% of the companies in the sample. These figures are much higher in 2008/10 survey: 53\%, 50\% and $32 \%$. The latest survey shows similar results in the countries of Central and Eastern Europe and Greece. The ratio of companies without trade union members is $37 \%$. The Hungarian ratio is higher, since half of the companies do not have trade union members; thus, our country is close to the US figure. The 2014/16 survey at the regional level shows a slight increase compared to the results of the previous survey in Hungary, however the same cannot be said about Greece (Table 4). There is a significant (Chi-Square $\mathrm{p}=0,000$ ) and weak (Cramer's V value 0,337 , or 0,309 ) correlation between the ratio of trade union members and the variables of country groups.

Several earlier research results support the 
fact that in Central and Eastern European countries the transition to capitalism (e.g. privatization, influence of direct investments) brought new challenges. The importance of trade unions has decreased, and the number of union members decreased (Dimitrova, 2005; Morley, et al., 2017; Scheuer, 2011). The current study confirms that the process has not finished yet. The influence of trade unions and their role in collective bargaining decreased in several countries, including Hungary as well (Table 4). The situation in Hungary and the region is showing similarities to Greece, where the importance of trade unions is weakening. Apart from the United Kingdom, the role and influence of trade unions and collective bargaining is stronger than in Central and Eastern Europe or Greece. We should emphasize that the Central and Eastern European countries do not form a homogeneous block in terms of labor market regulations and trade union traditions (Hill, 2015; Svetlik, et al., 2010). A previous study based on 2008/10 CRANET data (Morley, et al., 2017) also confirms that there are significant differences in labor related issues in the countries of the region.

While in Europe there is a clear tendency of weakening trade unions, the differences are strengthening between the countries and regions regarding the influence and the number of trade union members, as well as differences between liberal and coordinated market economies can be observed. The economically more developed regions show stronger trade union traditions than the Eastern and Central European region or Greece. Central and Eastern Europe is still suffering from the tradition of the socialist era, with a relatively strong tradition of trade unions in South Slavic countries. In former Yugoslavian states, German, and Scandinavian countries, where the trade unions are traditionally stronger (Hall \& Soskice, 2001), the results of two surveys show no change in strong trade union trends. The CEE countries (Hungary, Slovakia), South Europe (France, Greece), and the UK show a sharp decline in trade union activity. A direction convergence can be observed, and the results show convergence tendency between the countries of continental Europe and the USA (a country with strong trade union tradition).

\section{Flexible patterns of employment}

The opinion about flexible, atypical forms of employment have recently undergone significant change in Hungary and the neighboring countries. These forms of employment have gained the interest of employers as well. The introduction and frequency of these patterns of employment has widened. It is interesting to study how widespread these forms of employment are in different countries, especially in our region, where mixed attitudes can be identified towards atypical forms of employment (Antalik, et al., 2014). According to respondents of earlier research in Slovakia and Hungary (2012 and 2014), the management is more likely to introduce traditional patterns of employment, because most of the employees are reluctant to choose atypical employment patterns. The comparison of the research results shows a declining tendency of organizations unwilling to change their traditional patterns of employment.

The data of 2014/16 survey shows that the most widespread form of so-called atypical or flexible pattern of employment is the part-time job. About 91-99\% of the Western European and $85 \%$ of the US companies have introduced this pattern of employment, while it is less popular in the Central and Eastern European countries (68\%) and Greece (51\%). Hungary shows a bit higher ratio $(77 \%)$ of employees working parttime. Flexitime (71\%) and fixed-term employment (79\%) are also widely used patterns of employment. Flexitime is popular in Germanic and Northern countries. It is a characteristic pattern of employment with $90 \%$ of the companies, while only $30 \%$ of the companies apply it in Greece. The ratio of fixedterm employment is high (68\%-69\%) in the researched regions of Europe, while it is less popular in the USA (39\%). The least popular forms of employment are sub-contracted work and the compressed work week. The first is mainly popular in the UK (49\%), while the latest in the USA (49\%). Telework is also widespread in the USA (62\%) and the Germanic countries (53\%), while not so many countries in Central and Eastern Europe (23\%) and Greece (19\%) provide this possibility for their employees. Occasional work is widely practiced in Western 
and Northern Europe (61\%) and the USA (88\%), while in our region (e. g. CEE) and Hungary it is a less popular form of employment (39 and $25 \%)$, and it has even decreased since the first research was conducted (51\% and 33\%). It is presented on Figure 1.

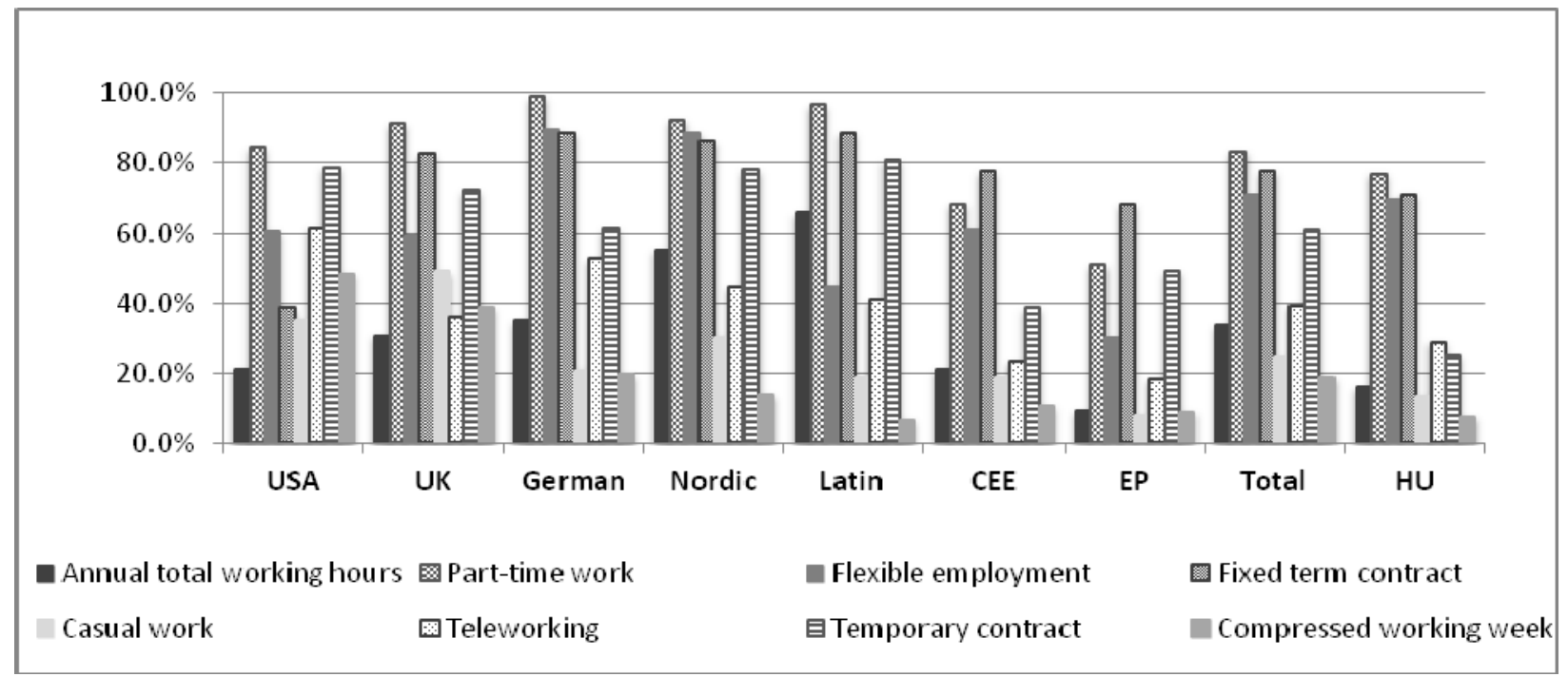

Figure1. Flexible patterns of employment based on the survey of 2014/16 (\%)

Source: Authors' own research

Comparing the latest results with the previous survey data, the US is showing a decreasing tendency of applying flexible patterns of employment, while most of the European country groups are characterized by moderate increase or stagnation. In Hungary, occasional work $(33 \%, 25 \%)$ is decreasing, while the ratio of part-time job $(60 \%, 77 \%)$ and telework $(21 \%, 29 \%)$ show a significant increase. The ratio of flexible working hours (70\% and $68 \%$ ) and telework (19\% and 23\%) has not changed significantly on regional level. Our 2012 and 2014 research results about the atypical patterns of employment showed similar results, where $68 \%$ and $58 \%$ was the ratio of part-time workers and $22 \%$ and $12 \%$ was the ratio of teleworkers in Hungary. The Slovak results show $46 \%$ and $58 \%$ of part-time workers and $24 \%$ of teleworkers in both surveys.

Despite the regional differences in the European countries, different types of flexible employment contracts are in line with the earlier research results (Brewster, 2007), and there are signs for directional convergences. The Central and Eastern European countries and the organizations in Greece are still weak in applying atypical patterns of employment. They lag behind the Western Europeans and the USA, but at the same time progress can be detected both in Central and Eastern Europe and Greece. In our region (e.g. CEE) the following patterns of employment are typical: fixed term employment contract, subcontracted work, telework, and flexitime, while stagnation is detected in part-time employment. The casual work, compressed work week and the annualised hours work contract show some decline. In spite of the outstanding differences in applying atypical forms of employment, CEE region is catching up with other European regions and the USA.

It would be a primary interest of each organization to adapt their operations to challenges of the external environment as quickly as possible. Different types of flexible employment patterns offer an excellent opportunity. Our previous research has shown that the economic crisis, fierce competition, and difficult price conditions force companies to take the benefits of atypical forms of employment seriously (Antalik, et al., 2013). 
These forms of employment provide potential for companies of the region. There is no doubt that the expansion of these is significantly influenced by rather negative attitude of employers and employees, as well as the negative influence of the state and legal regulations (Antalik, et al., 2014).

\section{Compensation - Incentives - Remuneration}

The CRANET survey focuses on two critical HR activities: a) collecting data in three different groups of employees (managers, professionals, administrative/blue collar workers); b) determining the basic salary level, the methods of financial participation, and the performancebased remuneration.

The least popular incentives are the employee stock options and portfolios. There is no significant difference between the regions regarding these types of incentives. Profit sharing is popular in France and the Germanic countries. It is not really popular in Hungary, Greece and Northern Europe. The strongest relation between the variables can be detected in case of profit sharing. Both surveys show the same tendency (2008/10: Cramer's V=0,3690,421, and 2014/16: Cramer's V=0,435-0,446). Flexible benefits show decline in most of the countries surveyed. In most of the cases it can be still recognized in the Anglo-Saxon countries (the USA, the UK), least can be detected in France, Greece and the Northern countries. Our region and Hungary are close to the average of the countries surveyed. The relationship between variables is the following: Cramer's $\mathrm{V}=0,263-0,302$, and $0,162-0,214$.

The most widespread forms of remuneration among the managers and employees in both survey periods are the performance-related wage and the performance-related bonus. The remuneration forms linked to individual performance are more popular in our region than the forms based on group performance. According to the latest survey, France and the UK are leaders in performance-related pay, while America, the Germanic countries, Greece, Central and Eastern Europe showed declining tendency in the period between the two surveys. The least they are practiced in the Northern European countries and Greece; their occurrence in Hungary is also below the regional average. At the same time, the Northern countries show significant increase in the popularity of performance-related pay for managers (22\% and 52\%), professional employees ( $17 \%$ and $48 \%$ ) and administrative staff (16\% and $40 \%)$. The strength between the correlation of variables in case of individual performance-related bonus (Cramer'sV $=0,222$ $0,305$, and $0,255-0,282)$ and the performancerelated pay (Cramer'sV=0,348-0,411, and 0,176$0,236)$ is worth mentioning.

Different movements are observed for each country group in case of performance-related forms of remuneration. Unlike the expectations, the use of the mentioned forms of remuneration has declined in the USA and most of the European countries, including the CEE countries and Greece. As we talk about declining tendency, the values seem to be closer in the USA, the Germanic countries, the Northern European countries, Central and Eastern Europe, including Greece as well. At the same time, an upward trend can be detected in the UK and France. Contrary to the findings of previous research (Brewster, 2007) we can speak neither about universal nor about direction convergence.

\section{Performance Appraisal}

The leaders and employees are involved in formal performance appraisal similarly, while the companies practice it less with blue-collar and administrative employees. According to $2008 / 10$ survey, about two-third of the companies (69\% and 67\%) used formal evaluation appraisal with their managers and employees, while the period between two surveys is characterized by slightly increasing tendencies (74\% and 73\%). It is not surprising that organizations of the liberal Anglo-Saxon market economies of the USA and the UK (Hall \& Soskice, 2001), and the Mediterranean (mixed) market economy, France (Hall \& Gingerich, 2004; Psychogios \& Wood, 2010) fall into this category. According to the survey conducted in 2014/16, about $94-97 \%$ of the organizations declared to use performance evaluation of their managers and professionals. 91-94\% of the companies use performance evaluation also in case of blue collar and administrative staff. It is the least characteristic 
in coordinated economies of the Northern European countries (Hall \& Soskice, 2001), where the influence of trade unions is strong. Roughly, half $(49 \%)$ of the companies in 2015/16 used performance appraisal. It shows an increase compared to earlier result of $42 \%$ (Figure 2).

The organizations of Central and Eastern Europe (71\% and 73\%) and Hungary (71-76\%) showed similar results to Germanic countries in 2014/16. While the ratio of companies applying performance appraisal in Germanic countries did not change significantly between the time interval of surveys, Central and Eastern Europe (from 63\% and 66\%) and Hungary (from 60\% and $59 \%$ ) show a significant increase. During the era of socialism, modern performance appraisal was not a HRM activity. The surveys conducted in the 90s (Pearce, 1991) show a complete absence of it, so our region shows a remarkable progress. There is a significant $(\mathrm{p}=0,000)$, and weak-medium relation between the variables (the Cramer's $\mathrm{V}$ value for managers is 0,292 , and 0,364 ; and 0,315 , and 0,335 for professional employees).

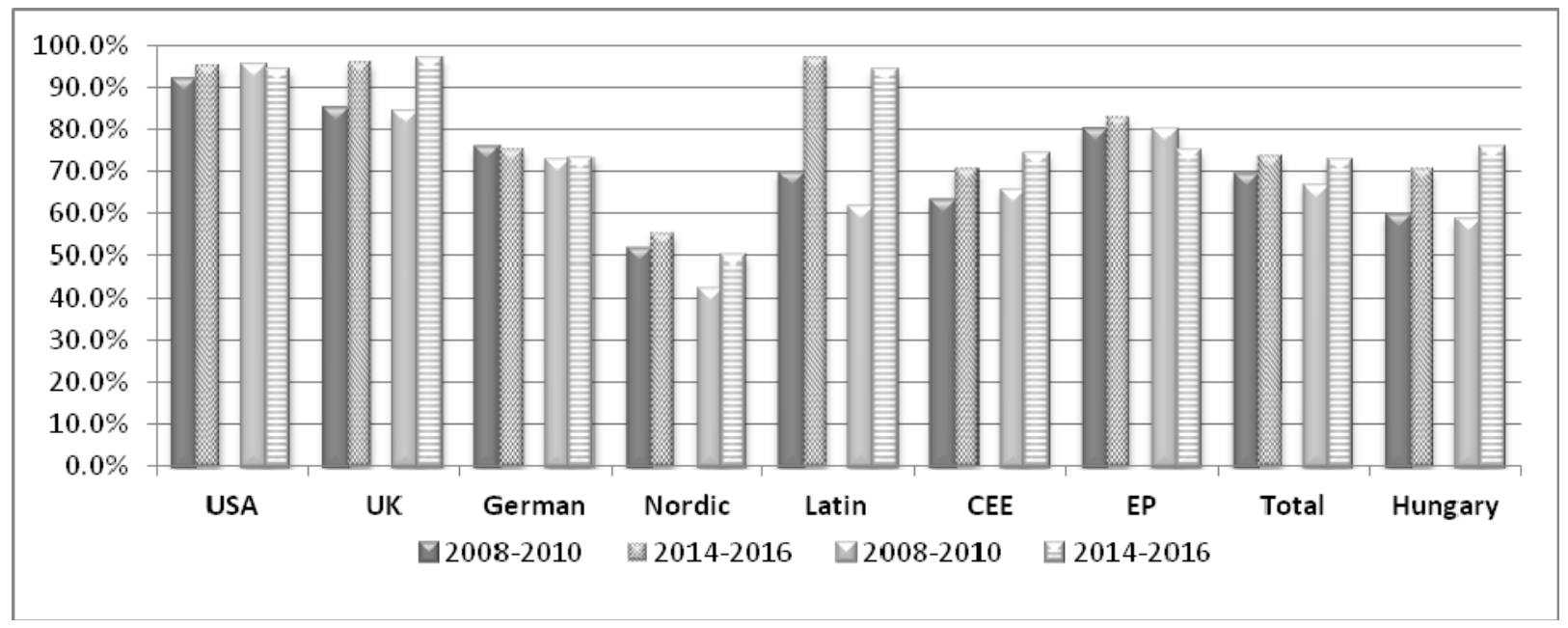

Figure 2. The ratio of organizations applying formal performance appraisal (\%)

Source: Authors' own research

An important indicator of applying evaluation appraisal is what additional HR work is supported by the evaluation results. Concerning the latter factor, it can be seen that the utilization of the results shows a slight decline, mainly in the USA and the Northern European countries, while significant growth can be detected in the UK and France. According to data from $2014 / 16,74 \%$ of the companies use these results for training and development, 73\% for career-related decisions, $70 \%$ utilize it in decision making connected to remuneration and $52 \%$ use them in planning the number of employees. The first three areas are used similarly in the Northern countries and the USA, while Western European countries and Greece apply it for training-development and making career decisions. Central and Eastern European countries, as well as Hungary utilize it in the field of remuneration. The Chi-Square test is significant in both periods $(p=0,000)$ and shows weak correlation (the Cramer'sV value is $0,177,0,221,0,173,0,15$, and $0,126,0,281$, $0,259,0,186$ ).

The use of performance appraisal is expanding in the examined regions, and nearly three quarters of the organizations today apply it as a part of their HR practice. Regional differences can be still detected. The leading position in the use of performance appraisal is dedicated to Anglo-Saxon countries (the USA, the UK) and France, while regional achievements are approaching the practices of liberal market economies (the USA, the UK). Despite of the rumors, performance appraisal is still popular. There has been a significant increase in Central and Eastern Europe, as well 
as in Hungary using performance appraisal. This shows that our region is catching up with the trend. The question is, whether it is getting closer to the Scandinavian-German model or leads towards convergence with the liberal market economy. If performance appraisal can be linked to the influence of trade unions, the latter is probable. There is also an opinion that transforming economies of the region represent different paths of development, and the institutional structure of more developed countries (Hungary, Slovakia) is closer to the model of coordinated market economy, while poorer countries (Bulgaria, Romania) follow the neo-liberal model (Lane, 2007).

The spread of performance appraisal in the examined country groups does not necessarily mean that its use in different HR decisions is also increasing.

It is not surprising that there is a strong positive correlation between the change in the use of performance appraisal results in decision making about remuneration and training and development $(R=0,881)$, change in the use of career decisions $(R=797)$ and between the change in use of career and training decisions $(\mathrm{R}=0,953)$. Those, who use performance appraisal results in decision making about remuneration are more likely to use them in training and career decisions, but they do not apply it for headcount planning. The change in the power of trade unions in country groups shows a strong reverse trend in the change of using the performance appraisal results in remuneration ( $R=-0,783)$, as well as in decisions about training and development $(\mathrm{R}=$ 0.815 ); and a slightly weaker relationship in the change of use in case of career and staff number decisions $(R=-0,686$; level 0,1$)$. The other variables did not show any significant correlation, but replacing four variables with their average, regarding the use of results of performance appraisal shows a strong negative relation $(R=-0,780)$. The latter relationship analysed on the level of countries will result in a strong regression model at 0,000 significance level with a coefficient of $-5,697$ and $R=0,752$ (Figure 3).

Thus, there is a negative linear regression relationship between the changes in the influence of trade unions and the change of the use of performance appraisal results in different decisions. In those countries or groups of countries where the power of trade unions has increased, the use of performance appraisal in different decisions such as remuneration, training and development, career moves, headcount planning has decreased, or vice versa, decreasing influence of trade unions „can help" the utilization of performance appraisal results in different decisions. 


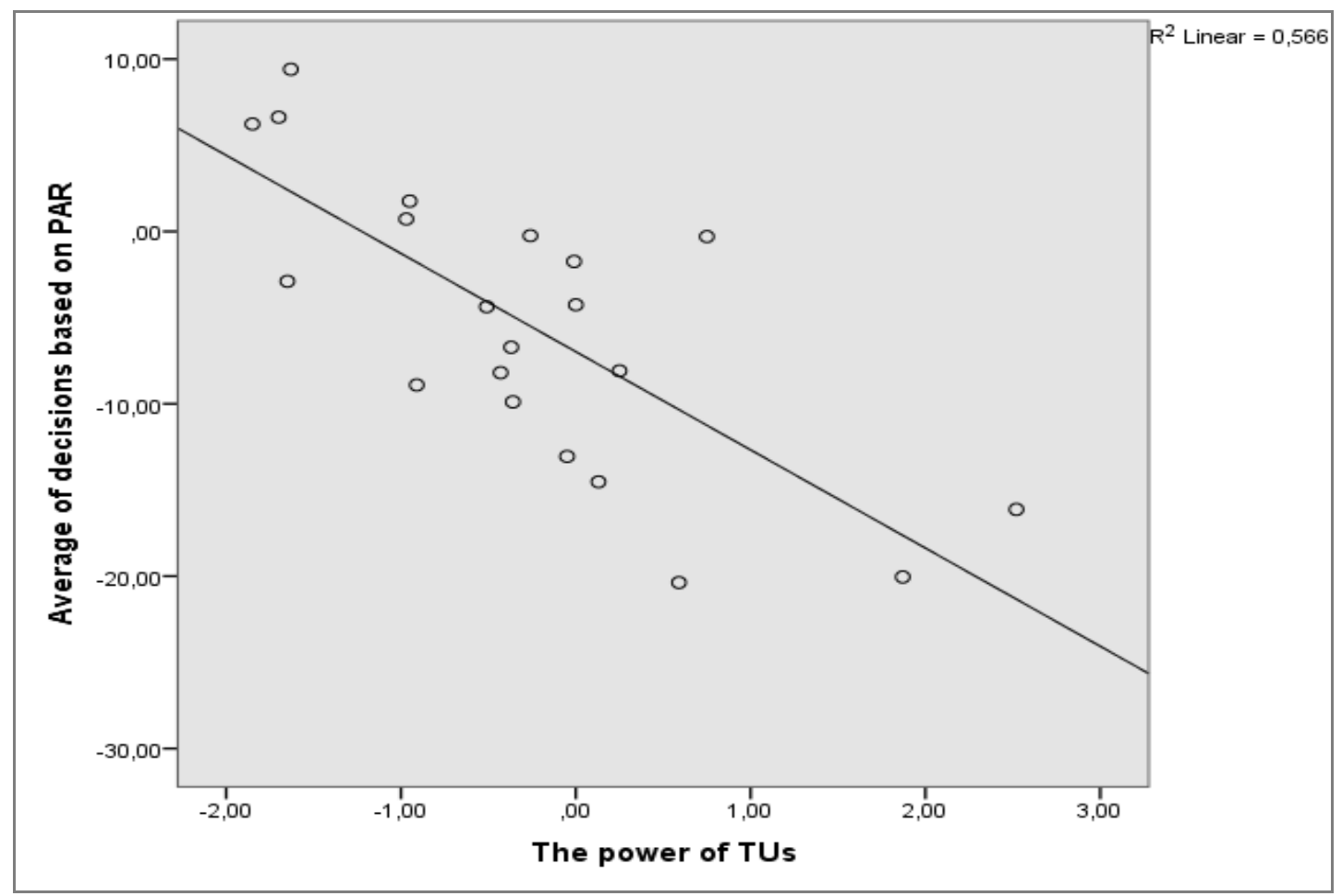

Figure 3. The power of trade unions and the average of decisions based on performance appraisal results

Source: Authors' own research

\section{The importance of $\mathrm{HR}$}

$15 \%$ of the surveyed organizations in $2008 / 10$, and $10 \%$ of them in $2014 / 16$ conducted their activity without employing a HR professional. At the same time, about a quarter of them had HR Department (more than 10 employees) in both survey periods. According to our previous research results, the ratio of organizations without employing HR staff has increased following the economic crisis in 2008. While there was a significant increase in Central and Eastern European countries and the UK, little change was detected in the countries of Northern and Western Europe. In post-crisis years (survey 2014/16), the ratio of organizations employing HR staff increased in each country group (Figure 4 ), and these results in most of the cases are close to the results of the pre-crisis survey of 2004/05. The strongest growth is seen where we saw the most significant decrease earlier (the UK, Central and Eastern European countries), but in our region it is still below the pre-crisis level. Although small companies (less than 250 employees) represent a much higher ratio in our region, their ratio has not changed significantly according to both survey results. The ratio of small companies has significantly decreased in the Hungarian sample, and a significant change in the number of organizations with $\mathrm{HR}$ departments (from 58\% to $80 \%$ ) could be recognized because of this fact. 


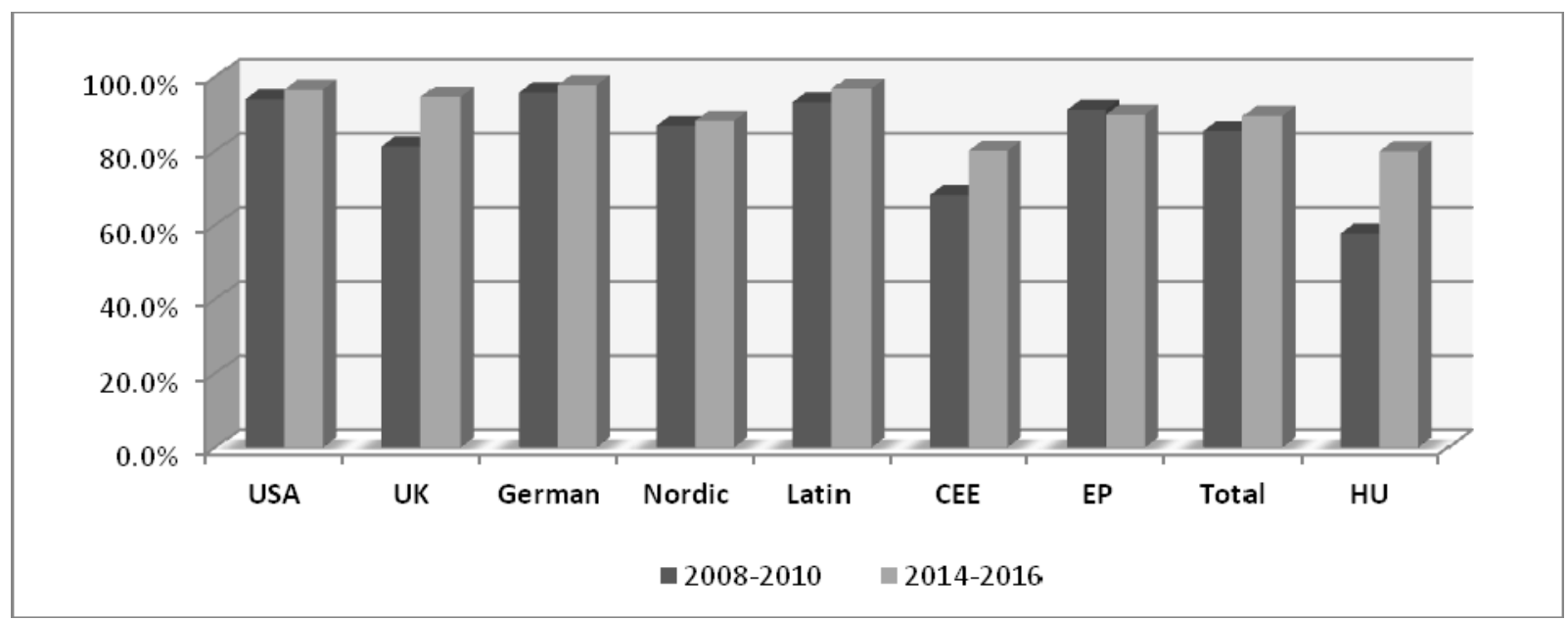

Figure 4. The ratio of companies with HR Department in country-groups (\%)

Source: Authors' own research

Typical respondents are organizations with 15 HR employees (44\% and 46\%). In the USA and the Germanic group there are hardly any respondents who do not employ HR staff, while in Central and Eastern Europe and Hungary they represent a much larger proportion of such organizations. The following graph demonstrates the comparison of HR Departments (Figure 5).

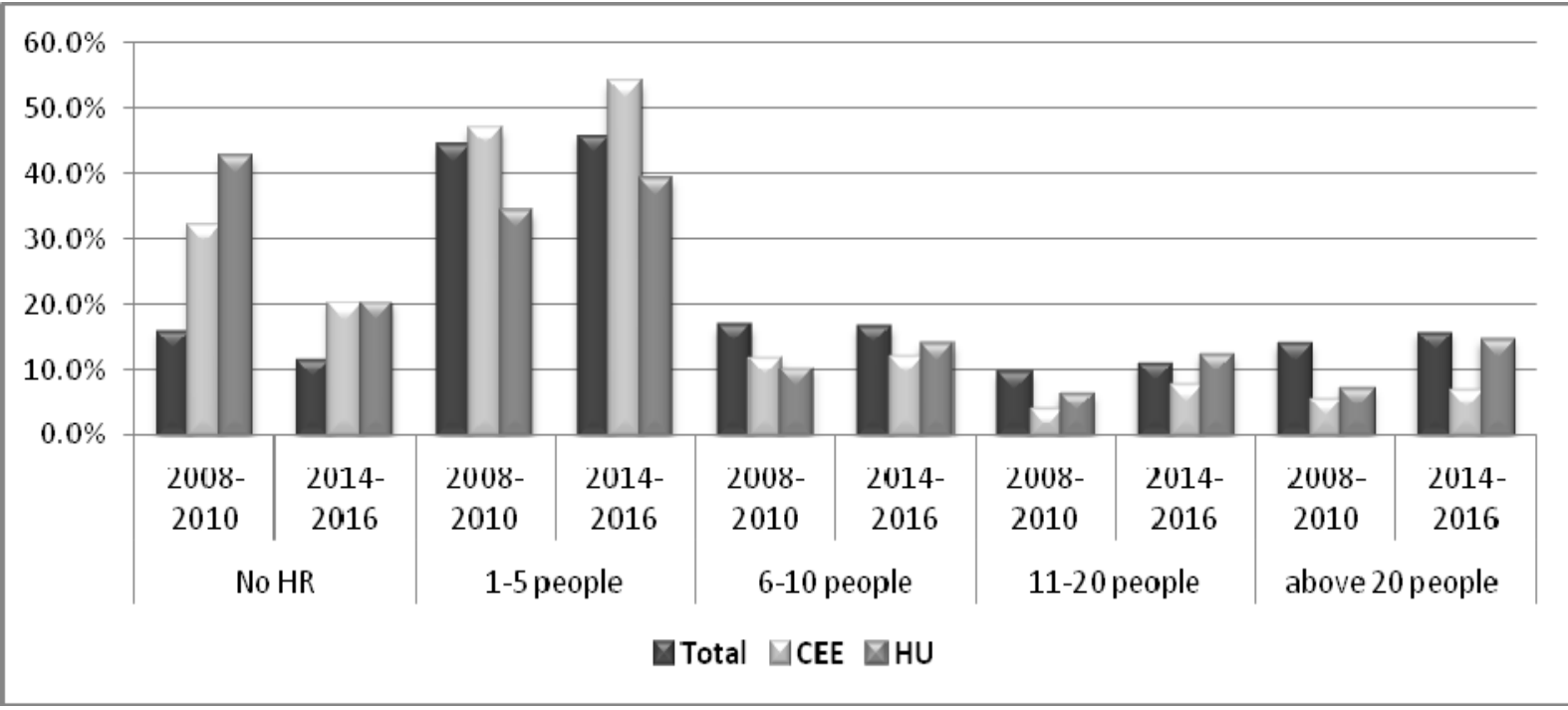

Figure 5. The size of the HR Department (\%)

Source: Authors' own research

Hungarian organizations show similar results to the countries of Central and Eastern Europe, but our region is still lagging behind the USA and other countries of Europe. There is a significant correlation between the existence of HR Departments and the country clusters in both of the survey periods (Chi-Square Test $\mathrm{p}=0,000)$, the value of the association coefficient (Cramer'sV), indicating the strength of relationship is 0,296 , and 0,229 . It indicates a weak relationship, which shows weaker result in the second sample. The number of companies with HR Departments has increased, while differences between the regions 
decreased, resulting in direction convergence (Brewster, 2007).

In two-thirds of the surveyed organizations, the person responsible for $H R$ tasks is a member of the top management as well. It can be declared about the French (88\%), NorthEuropean (78\%) and the UK (77\%) organizations. The Germanic countries show lower ratio (54\%), even stagnation can be detected. In Central and Eastern Europe there is a decline from $73 \%$ to $58 \%$ because of the Hungarian organizations. It shows a decreasing tendency of organizations (from $87 \%$ to 57\%) where the employee responsible for HR tasks is a member of the top management as well. Although the CEE and the Hungarian samples are mainly represented by companies with less than 250 employees, it does not provide an explanation for the decline, because there is no significant change regarding the composition of the employee number and the sector (private/public) in the survey samples. The Chi-Square Test shows significant relationship in both cases $(p=0,000)$, and the value of Cramer'sV $(0,205$, and 0,218$)$ indicates a weak relationship between the variables.

The number of companies/organizations with a written HR strategy has increased from $54 \%$ to $66 \%$. The increase (from $44 \%$ to $62 \%$ ) is considerably higher in Central and Eastern Europe. It does not lag behind the USA trend (65\%) and the rest of the surveyed European countries (60-69\%). Higher ratio (76\%) can be detected in Northern Europe. The ratio of companies/organizations with a written HR strategy in Hungary is below the regional average, and the rate of growth is also lower (from $42 \%$ to $55 \%$ ). There is significant (ChiSquare, $p=0,000$ ) but weak (Cramer's $V=0,202$, and 0,128 ) relationship between the variables. The existence of a written HR strategy is less dependent on a country-group in the second survey. The individual regions show the same direction, so we can see an increase in the number of companies with a written HR strategy in different country-groups.

The involvement of HR in development of business strategy and consultation is characteristic for the majority of companies in the sample and does not show significant change (90\% and $89 \%$ ). The highest ratio is represented by organizations in France (96\%), the UK (94\%) and the organizations of Northern Europe (93\%). The Central and Eastern Europe (from $91 \%$ to $86 \%$ ), especially the Hungarian results (from 93\% to $71 \%$ ) show significant decline. Slightly more than half of the companies utilize HR activities during the development of business strategy, although there is a significant difference between the country clusters. The highest ratio is represented by the French $(71 \%)$ and Northern European (64\%) organizations, while in the USA 44\% and Greece 40\%. In Central and Eastern Europe this ratio stands at $40 \%$, which means $10 \%$ decrease compared to results of the previous survey. Hungary shows a decline from $61 \%$ to $44 \%$. There is a significant correlation between the country clusters and the involvement of HR activities in business strategy development (Chi-Square Test, $\mathrm{p}=0,000)$, but the correlation is weak (Cramer'sV: 0,141, and 0,147).

Table 5 presents the comparison of the last three CRANET survey results. The figures in parenthesis with data from 2008/10 show results of the earlier survey. The difference derives from the fact that the current analysis focuses on those countries, which were involved in the last two surveys. In 2008/10 a significant improvement in this field can be detected not only globally, but regionally as well. The latest results show significant decline in both areas, especially the issue regarding the involvement of $\mathrm{HR}$ leader in the top management. 
Table 5. HR's organizational position-binary logistic regression models

\begin{tabular}{|l|c|c|c|c|c|c|}
\hline Countries & \multicolumn{2}{|c|}{$2004 / 2005$} & \multicolumn{2}{c|}{$2008 / 2010$} & \multicolumn{2}{c|}{$2014 / 2016$} \\
\cline { 2 - 7 } & $\begin{array}{c}\text { HR leader in } \\
\text { the top } \\
\text { management }\end{array}$ & $\begin{array}{c}\text { HR leader } \\
\text { involved in } \\
\text { strategy } \\
\text { developmen } \\
\mathrm{t}\end{array}$ & $\begin{array}{c}\text { HR leader in } \\
\text { the top } \\
\text { management }\end{array}$ & $\begin{array}{c}\text { HR leader } \\
\text { involved in } \\
\text { strategy } \\
\text { development } \\
\text { the top } \\
\text { managemen } \\
\text { t }\end{array}$ & $\begin{array}{c}\text { HR leader in } \\
\text { involved in } \\
\text { strategy } \\
\text { developmen } \\
\text { t }\end{array}$ \\
\hline Hungary & 47 & 49 & $87(87)$ & $93(91)$ & 57 & 71 \\
\hline $\begin{array}{l}\text { Central and } \\
\text { Eastern Europe }\end{array}$ & 52 & 41 & $73(62)$ & $91(88)$ & 58 & 86 \\
\hline All countries & 55 & 52 & $68(67)$ & $90(90)$ & 66 & 89 \\
\hline
\end{tabular}

Source: Authors' own research

The examination of variables describing the position of HR departments in organizations shows a significant, but weak correlation with the country clusters in both research samples. Membership of the countries in clusters has more or less an impact on the HRM activities of the organizations. While there was significant increase in the number of organizations with functioning HR Departments and a written HR strategy, HR seems to disappear from top management and the business strategy development as well. Although small companies (less than 250 employees) represent a higher ratio in our region, their ratio has not changed on regional level according to both surveys, while the Hungarian sample shows decline. We cannot ignore the fact that the ratio of public sector organizations has also increased at regional level and Hungary as well. At the same time, the ratio of public sector in the latest US and Northern European samples is even higher than the Central and Eastern European, but negative tendencies cannot be detected in either of them.

We have made a multivariate analysis to find out which factors will determine, whether the person responsible for HR tasks is a member of top management or not; involved in development of the company strategy; is there a written HR strategy in the company. Relying on the survey data 2014/16, we used a logistic regression analysis to examine the factors influencing the position of $\mathrm{HR}$ in the organization. The binary logistic regression is a classification method, which allows nominal category variables in the regression model. The observations based on information obtained from the explanatory variables are categorized into one of the predefined, mutually exclusive groups.

The bivariate analyses show that variables (grouping countries into clusters, size of the company/number of employees, sector the company belongs to, influence of trade unions) have more or less impact on whether the HR leader is a member of the company's/organization's top management. Binary logistic regression was used to investigate the combined effect of these variables. The result of Hosmer\&Lemeshow homogeneity test is Sig=0,113, while the explanatory power of the model (Cox\&Snell $\mathrm{R}$ Square, Nagelkerke R Square) was fairly low despite the significant effects $(0,169$ and 0,238$)$. The accepted model rated the cases reliably (73\%). In case of logistic regression, the first category was considered as a reference category and the impact of other categories on occurrence probability can be examined compared to that. Table 6 summarizes which explanatory variables have significant impact on whether an employee responsible for HR tasks is a member of the top management or not.

The existence of HR Department and the influence of trade unions have no significant effect, however belonging to private/public or non-profit sector and the organization size can predict, whether the employee responsible for HR is a member of the top management or not. Belonging to public, non-profit, or mixed sector (compared to private sector) shows negative correlation, while the increase in size of the organization reflects stronger positive correlation. The CEE and Germanic countries, as well as Greece (the latter at 0,1 significance 
level) show a negative relationship compared to the USA. There is significant correlation with the written HR strategy and the strategy consultation as well; the latter shows the strongest positive correlation in case of the category "from the beginning". Based on all of these explanatory variables, the participation of HR professional in top management is $73 \%$ correctly classified by the model.

Table 6. The importance of HR in 2004/2005, 2008/20010 and 2014/2016, based on CRANET samples (\%)

\begin{tabular}{|c|c|c|c|c|c|c|c|c|c|}
\hline \multirow[t]{2}{*}{ Variables } & \multicolumn{3}{|c|}{$\begin{array}{c}\text { HR in top } \\
\text { management }\end{array}$} & \multicolumn{3}{|c|}{$\begin{array}{c}\text { Strategic } \\
\text { consultation from } \\
\text { the beginnings }\end{array}$} & \multicolumn{3}{|c|}{ Written HR strategy } \\
\hline & B & df & Sig. & B & $\mathrm{df}$ & Sig. & B & df & Sig. \\
\hline the USA & & 6 & 0,000 & & 6 & 0,000 & & 6 & 0,001 \\
\hline the UK & $-0,225$ & 1 & 0,444 & 0,414 & 1 & 0,098 & $-0,426$ & 1 & 0,140 \\
\hline German & $-1,257$ & 1 & 0,000 & 0,639 & 1 & 0,002 & $-0,471$ & 1 & 0,057 \\
\hline Nordic & $-0,106$ & 1 & 0,659 & 0,579 & 1 & 0,005 & 0,120 & 1 & 0,630 \\
\hline Latin & 0,324 & 1 & 0,385 & 0,908 & 1 & 0,001 & $-0,460$ & 1 & 0,151 \\
\hline CEE & $-0,523$ & 1 & 0,025 & $-0,191$ & 1 & 0,350 & 0,041 & 1 & 0,865 \\
\hline Eastern Periphery & $-0,525$ & 1 & 0,073 & $-0,086$ & 1 & 0,743 & $-0,049$ & 1 & 0,872 \\
\hline $\begin{array}{l}\text { Is there a written HR } \\
\text { strategy }\end{array}$ & 0,239 & 1 & 0,024 & 0,605 & 1 & 0,000 & & & \\
\hline $\begin{array}{l}\text { HR not consulted in } \\
\text { business strategy } \\
\text { development }\end{array}$ & & 3 & 0,000 & & & & & 3 & 0,000 \\
\hline $\begin{array}{l}\text { HR consulate on } \\
\text { implementation of business } \\
\text { strategy }\end{array}$ & 0,404 & 1 & 0,016 & & & & 0,900 & 1 & 0,000 \\
\hline $\begin{array}{l}\text { HR involved through } \\
\text { subsequent consultation }\end{array}$ & 1,110 & 1 & 0,000 & & & & 1,079 & 1 & 0,000 \\
\hline $\begin{array}{l}\text { HR involved in business } \\
\text { strategy development from } \\
\text { the outset consultation } \\
\text { from the beginning }\end{array}$ & 2,016 & 1 & 0,000 & & & & 1,393 & 1 & 0,000 \\
\hline Sector- private & & 3 & 0,000 & & 3 & 0,761 & & 3 & 0,808 \\
\hline Sector -public & $-0,691$ & 1 & 0,000 & 0,061 & 1 & 0,589 & 0,034 & 1 & 0,793 \\
\hline Sector - non-profit & $-0,853$ & 1 & 0,000 & 0,185 & 1 & 0,370 & $-0,195$ & 1 & 0,371 \\
\hline Sector - mixed & $-0,536$ & 1 & 0,033 & $-0,075$ & 1 & 0,753 & 0,002 & 1 & 0,993 \\
\hline Employees under 250 & & 3 & 0,001 & & 3 & 0,096 & & 3 & 0,000 \\
\hline Employees 250-1000 & 0,245 & 1 & 0,030 & 0,203 & 1 & 0,053 & 0,225 & 1 & 0,044 \\
\hline Employees 1001-5000 & 0,315 & 1 & 0,027 & 0,273 & 1 & 0,034 & 0,632 & 1 & 0,000 \\
\hline Employees over 5000 & 0,839 & 1 & 0,000 & 0,324 & 1 & 0,075 & 0,922 & 1 & 0,000 \\
\hline Existing HR Department & $-0,024$ & 1 & 0,888 & $-0,747$ & 1 & 0,000 & 1,500 & 1 & 0,000 \\
\hline Influence of trade unions & 0,026 & 1 & 0,521 & 0,098 & 1 & 0,008 & 0,053 & 1 & 0,200 \\
\hline HR in top management & & & & 1,354 & 1 & 0,000 & 0,235 & 1 & 0,027 \\
\hline Invariant/constant & $-0,129$ & 1 & 0,671 & $-1,251$ & 1 & 0,000 & $-1,789$ & 1 & 0,000 \\
\hline
\end{tabular}

Source: Source: Authors' own research

As we have seen, there is a significant, but weak correlation between the country clusters and the organization having a written HR strategy or not. The Germanic country cluster had the lowest number of companies (60\%) with a written HR strategy. The regression model complied with the homogeneity test ( $\mathrm{Sig}=0,430$ ), the explanatory power of the model was 0,114 , 
and 0,166 . The classification shows $75 \%$ reliability. The results show a significant (negative) correlation at significance level 0,1 only for one country cluster, the German group. The sector and the influence of trade unions have no significant impact, but the other variables do. The existence of HR Department and the increasing number of employees are also a strong positive predictor of the HR strategy (Table 6).

Based on two-variable analyses, there is a significant weak relationship between the country clusters and the level of business strategy consultation. In the category „from the beginning", the organizations of CEE countries and Greece represent the lowest rate (40 and $41 \%)$, somewhat behind the economically developed countries. The category of strategy consultation "from the beginning" shows the most striking relationship with the HR strategy and participation of $\mathrm{HR}$ in top management. Therefore, the answers to strategic consultation were divided into two dichotomous categories: $1=$ consultation from the beginnings, $0=$ no consultation or only partial consultation exists. Regression analysis was conducted for this variable, and as a result, the variable complies with the homogeneity test $(S i g=0,270)$, its explanatory power was 0,152 , and 0,203 , and the classification shows $68 \%$ reliability. All Western and Northern European country clusters (compared to the USA) show a positive significant effect. The relationship with employee number is significant at 0,1 level. Since significant sectoral effects are not detected, the strategic consultation from the beginning does not depend on whether the organization operates as public, private or nonprofit. In addition, there is a significant, strong, positive relationship with the written HR strategy and the participation of employee responsible for HR activity in the top management (Table 6).

Based on these facts, the size of the organization (the number of employees) has a strong, positive predictive role to determine the role of HR in the organization: the larger the company is, the higher is the probability of the existence of HR Department; the HR is more engaged in top management tasks, there is clear HR strategy, and strategic consultation with HR is applied from the beginning. The size of the organization has an impact on the role of HR in the organization, but the involvement of HR in top management is also determined by belonging to the private sector, while the predictability of trade union influence is negligible even in significant cases. The membership in country clusters has a predictable role in case of variables discussed above in different ways.

It is clear that the role of $\mathrm{HR}$ in the organization is primarily influenced by the size of the organization, but the significance of representing the CEE bloc or Greece cannot be ignored either. This emphasizes the priority of the issue in our region.

\section{CONCLUSIONS}

The research based on the latest two CRANET surveys focuses on the changes in HR area since the recent economic crisis. Our study focuses on six European regions and the USA, looking for Central and Eastern European, as well as Hungarian features. Our findings on convergence and divergence can be interpreted according to this.

We have found a significant relationship between HR practices and the grouping of countries with respect on cultural and institutional features. This correlation is weak in most of the cases or medium strength sometimes. Certain areas of HR activity are affected by the country cluster the organization belongs to. The cultural and institutional environment is influencing the HR activity, so diversity of the European HRM practice is still characteristic (Brewster, 2004, 2007; Mayrhofer, et al., 2004). This is consistent with the findings related to the contextual dependence of HR practices and denies the idea of universal spread and applicability of „best practices”. It also confirms the results that HR practices in former socialist countries form a distinct region in Europe. According to our survey results, even the economically developed North and West European economies cannot be treated as a single block regarding the HRM practice. The UK, France, the German and Scandinavian clusters show different characteristic features, as well as liberal market economies and coordinated market economies (Hall \& Soskice, 2001) can be 
clearly distinguished from each other in their HR characteristics. Divergent trends typical for HRM practices of the European countries and regions can be still detected today, while well-perceived similarities and convergent processes can be identified as well. The findings are similar to previous research results regarding the size of HR Departments and the use of flexible patterns of employment (Brewster, 2007). Directional convergence, as well as divergence can be detected in some areas. Despite the earlier assumptions and the globalization effect, there is no straightforward path towards the unification of HR practices.

A remarkable trend is the convergence of the US HR practices and the practices of the coordinated market economies of the European countries, which is reflected in strengthening trade unions and the decreasing performancebased remuneration and utilization of performance appraisal results. A reverse, not so strong relationship can be recognized between the strength of trade unions and the performance-based remuneration, and the performance appraisal.

Different sub-areas of HR practice in the CEE region and Hungary show similarities to the international tendencies, while specific forms of HRM practice are still present. The countries of the region, including Hungary are approaching the HR practices of the economically developed regions of the world in the following: the proportion of organizations with HR Departments and HR strategy, performance appraisal, and applying atypical forms of employment. Although the organizations of CEE countries have recognized the importance of performance appraisal or utilization of atypical patterns of employment, the strategic role of HR does not show the same success. The results suggest that employees responsible for HR tasks in the CEE region and Hungary are less involved in the work of top management and participate less in elaboration of the business strategy.

Although consecutive CRANET surveys have consistently demonstrated their usefulness in examining and comparing HR practices, we also call attention to the limitations of our research. First of all, it is very likely that they will respond to the questionnaire, who take their own HR role seriously. This is presumably related to the importance of $\mathrm{HR}$ functions in a given organization, so those companies where HR functions gain less importance might be underrepresented in the sample (Croucher, et al., 2010). Secondly, CRANET surveys are not panel tests, so the respondents in each cycle are not the same. Despite the fact that only the countries that participated in both of the surveys were involved in the analysis, the different set of organizations in the sample and the resulting different characteristics of the sample may distort temporal comparison from a certain point of view. Finally, despite the fact that the countries of the CEE region have been identified as a cluster by several cultural studies (Gupta, et al., 2002; Inglehart \& Baker, 2000) and undoubtedly link them to multi-decade socialist past, a communist economic experiment, and thus a number of common specifications (and at the same time they differ from the developed economies of Western Europe), can hardly be considered a homogeneous region (Bakacsi, 2008; Brewster \& Bennett, 2010; Brodbeck, et al., 2000; Lane, 2007). Rather, it is a heterogeneous area, where joint movements as well as divergent features can be observed. According to Lane (2007), these countries represent different paths of capitalist development. This can also be manifested in a number of HR variables. The examination of different HR variables by country may therefore be a justified research direction.

Although HR is not only and not primarily the work of HR specialists, but also a major part of management, it is also desirable that HR should have a place and role in the top management and strategy of the company. At the same time, it is important that the senior management's viewpoint also prevails in HR operation. If we start from Ulrich's role model, the role of HR's "Strategic Partner" must be strengthened in the organizations of the region and not least in Hungary (Ulrich \& Brockbank, 2005). The same can be said about the role of "Employee Champion", which can be strengthened especially in countries where the role and strength of trade unions is declining, including Hungary. This is not a small challenge for the region's organizations and $\mathrm{HR}$, as there is a great contradiction between the requirements of these two roles. We believe that proper preparation and further training of $\mathrm{HR}$ 
professionals and company executives can be an important factor in enabling companies in the region to cope with the practice of industrially developed regions; this would require a change in the mindset and attitude of small and medium-sized companies, in the SME sector. In this segment, the application of advanced HR and management skills and techniques is the most urgent, as previous research (Kovács \& Poór, 2017) has also confirmed that bigger the company is, the position and strategic role of HR is stronger. According to Ulrich (2015), which has been quoted several times earlier, HR professionals do not have to work on improving organizational forms and structures, but their most important task will be to develop the skills and competences of those employed.

\section{ACKNOWLEDGMENTS}

In performing this assignment, the authors express their gratitude to Cranet research network members for ongoing professional support.

\section{REFERENCES}

Adler, N. (1983). A typology of management studies involving culture. Journal of International Business Studies, 2, 29-47.

Amable, B. (2003). The Diversity of Modern Capitalism, Oxford. Oxford University Press.

Antalik, I., Juhász, T., Kovács, I.É. , Madarász, I., Poór, J. \& Szabó, I. (2013). Research on the employent of atypical forms of employment, non-market employment and cross-border cooperation in the Komárno-Komárom region. Research Study on Support for Future Workplaces, (In Hungarian) GödöllöKomárno, Selye János University, Komarno Szent István University.

Antalik, I., Dús, M., Gábrielné Tőzsér, Gy., Gősi, M., Horbulák, Zs., Juhász, T., Kollár, Cs., Kovács, I.É. , Madarász, I., Mihály, N., Poór, J., Strázovská, H., Strázovska, G., Szabó, I., Szabó, K. \& Vinogradov, Sz. In: Poór J. (2014) Employment - atypical employment in the Hungarian-Slovak border area - Komárno Komárom and Párkány - Esztergom regions. Visegrad Fund. Research report, (In Hungarian) Gödöllö-Komárno, Selye János University, Komarno - Szent István
University.

Armstrong, M., Taylor, S. (2014). Armstrong's Handbook of Human Resource Management Practice. 13th edition. Kogan Page, London

Bakacsi, Gy. (2008). Research report on the richness and culture - cultural determinism of future-oriented competitiveness (GLOBE research) c. T044689 record number OTKA research. Budapest.

Boxall, P., Purcell, J. (2003). Strategy and Human Resource Management. New York: Palgrave Macmillan. Brewster, C. (1995). Towards a European model of human resource management. Journal of International Business Studies, 26, 1, 1-21.

Brewster, C. (1999). Strategic human resource management. The value of different paradigms. Management International Review, 39, 45-64.

Brewster, C. (2004). European perspectives on human resource management. Human Resource Management Review, 14, 365-382.

Brewster, C. (2007). A European perspective on HRM. European J. International Management, 1, 3, 239-259.

Brewster, C., Mayrhofer, W., Morley, M. (2004a). The concept of strategic European human resource management. In: Brewester, C.Mayrhofer, W.-Morley, M. (Eds.): New Challenges for European Human Resource Management. Macmillan, London.Brewster, C. \& Bennett, C. V. (2010). Perceptions of business cultures in Eastern Europe and their implications for international HRM. The International Journal of Human Resource Management, 21, 14, 2568-2588

Brewster, C., Morley, M. \& Buciuniene, I. (2010). The reality of human resource management in Central and Eastern Europe. Baltic Journal of Management, 5, 145-155.

Brodbeck, F., Frese, M., Bakacsi Gy. et al. (2000). Cultural Variation of Leadership Prototypes Across 22 European Countries, Journal of Occupational and Organizational Psychology, 73, 1-29.

Csillag, S. (2014). Az emberierőforrásmenedzsment mint morális útvesztő. Etikai kérdések az emberierőforrás-menedzsment tevékenységben. BGF-Emberi Erőforrások 
Minisztériuma.

Croucher, R., Brookes, M., Wood, G. \& Brewster, C. (2010). Context, strategy and financial participation. A comparative analysis. Human Relations, 63, 6, 835-855.

Dimitrova, D (2005). Looking Ahead. Trade Union Strategies for Decent Work. In: Dimitrova, D., Vilrokx, J. (eds) Trade Union Strategies in Central and Eastern Europe. Towards Decent Work. Budapest. International Labor Office.

Due, J., Madsen, J. S., Jansen, C. S. (1991). The social dimension. Convergence or diversification of IR in the single European market? Industrial Relations Journal, 2, 85102.

Granell, E. (2000). Culture and globalization. A Latin American Challenge. Industrial and Commercial Training. Vol.32. No.3. pp. 8994.

Guest, D. E. (1990). Human resource management and the American dream. Journal of Management Studies, Vol. 27, No. 4, pp.377-397.

Gupta, V., Hanges, P.J. \& Dorfman, P. (2002). Cultural clusters. Methodology and findings. Journal of Word Business,37,1,11-15

Hall, P.A., Gingerich, D.W. (2004). Varieties of Capitalism and Institutional Complementarities in the Macroeconomy. An Empirical Analysis. MPIfG Discussion Paper 04,5, Cologne. Max-Planck-Institut für Gesellschaftsforschung.

Hall, P.A., Soskice, D. (2001). An Introduction to the Varieties of Capitalism. In P. Hall and D. Soskice (eds.), Varieties of Capitalism. The Institutional Basis of Competitive Advantage, Oxford. Oxford University Press.

Hancke, B., Rhodes, M. \& Thatcher, M. (2007). Introduction' In. Hancke, B., Rhodes, M., Thatcher, M. (Eds.) Beyond varieties of capitalism. Conflict, contradiction, and complementarities in the European economy. Oxford. Oxford University Press.

Harrison, L. E. (1985). Underdevelopment is a State of Mind. The Latin American Case. University Press of America.

Hickson, D., Himngs, C., McMillen, C. \& Schnitter, J. (1974). Culture free context of organization structure. Sociology, 8, 59-80.

Hill, C (2015). International Business. New York. McGraw-Hill.

Hofstede, G. (1980). Culture's consequences. International differences in work-related values. Sage Publications, Beverly Hills

Inglehart, R., Baker, W. E. (2000). Modernization, Cultural Change, and the Persistence of Traditional Values. American Sociological Review, 65, 19-51.

Kelley, L., Whatley, A., Worthley, R. \& Chow, I. (1995). Congruence of national managerial values and organizational practices. A case for uniqueness of the Japanese. Advances in International Comparative Management, 10, 185-99.

Kerr, C., Dunlop, J., Harbinson, F., Myers, Ch. (1960). Industrialism and industrial man. Cambridge. Harvard University Press.

Koopman, P. L., Den Hartog, D. N., Konrad, E., Bakacsi, Gy. et al. (1999). National Culture and Leadership Profiles in Europe. Some Results from the GLOBE Study. European Journal of Work and Organizational Psychology, Special Issue on Organizational Culture, 8, 4, 503-520.

Kovács I. É. \& Poór J. (2017). Quo vadis HRM? HR practices in CEE countries. (in Hungarian) In Farkas A., F. Orosz S.\& Rudnák I. (Eds.) Branches of Sciences in Multicultural Context. Gödöllö: Szent István University Publishing House.

Lane, D. (2007). Post-State Socialism. A Diversity of Capitalisms? In. Lane, D., Myant. M. (eds). Varieties of Capitalism in Post-Communist Countries, London. Palgrave, 13-39.

Lazarova, M., Morley, M. \& Tyson, S. (2008). Introduction-International comparative studies in HRM and performance - the Cranet data. The International Journal of Human Resource Management, 11, 19952003.

Landes, D. S. (1998). The Wealth and Poverty of Nations. Why Some Are So Rich and Some So Poor. London-New York. W.W. Norton \& Company.

Legge, K. (2005). Human Resource Management: Rhetorics and realities. Basingstoke, Macmillan, UK 
Mayrhofer, W. (1998). Between market, bureaucracy and clan. Coordination and control mechanisms in the Cranfield Network on European Human Resource Management (Cranet-E). Journal of Managerial Psychology, 3, 241- 258.

Mayrhofer, W., Morley, M. \& Brewster, C. (2004). Convergence, Static, or Divergence? In: Brewster, C., Mayrhofer, W., Morley, M. (eds.). Human Resource Management in Europe. Evidence of Convergence? London. Elsevier.

Michailova, S., Heraty N., Morley M. (2009). Studying Human Resource Management in the International Context: The Case of Central And Eastern Europe. In: Morley, M., Heraty,N., Michailova, S. (Eds.): Managing Human Resources in Central and Eastern Europe, London: Routledge, pp.1-24.

Morley, M. J. \& Collings, D. G. (2004). Contemporary debates and new directions in HRM in MNCs. International Journal of Manpower, 6, 487-499.

Morley, M., Heray, N., Michailova, S (eds.) (2009). Managing Human Resources in Central and Eastern Europe, London. Routledge.

Morley, M., Poór, J., Slavic, A., Berber, N. (2017).

The Features of Industrial Relations in Central and Eastern Europe. Evidences based on Cranet research. (unpublished manuscript)

Mullins, L.J. (2005). The management and Organizational Behavior. Prentice HallFinancial Times, Edinburgh.

North, D. C. (2005). Understanding the Process of Economic Change, Princeton. Princeton University Press.

Pearce, J. L. (1991). From socialism to capitalism; the effects of Hungarian human resources practices. Academy of Management Executive, 5, 4, 75-88.

Poutsma, E., Ligthart, P. E. M. \& Veersma, U. (2006). The Diffusion of Calculative and Collaborative HRM Practices in European Firms. Industrial Relations, 45, 4, 513-546.

Psychogios, A. \& Wood, G. (2010). Human Resource Management in Greece in Comparative Perspective. Alternative
Institutionalist Perspectives and Empirical Realities. International Journal of Human Resource Management, 21, 14, 2614-2630.

Ronen, S., Shenkar, O. (1985). Clustering countries on attitudinal dimensions. A review and synthesis. Academy of Management Review, 10, 3, 435-454.

Scheuer, S. (2011). Union membership variation in Europe. A ten-country comparative analysis. European Journal of Industrial Relations, 17, 1, 57-72.

Smith, P.B., Dugan, S. \& Trompenaars, F. (1996). National culture and the values of organizational employees. Journal of CrossCultural Psychology, 27, 231-264.

Sparrow, P., Schuler, R., Jackson, S. (1994). Convergence or divergence. Human resource practices and policies for competitive advantage worldwide. International Journal of Human Resource Management, 2. 267299.

Svetlik, I., Barisic, A. F., Kohont, A., Petkovic, M., Aleksic Miric, A., Slavic, A. \& Poor, J. (2010). Human Resource Management in the Countries of the former Yugoslavia. Review of International Comparative Management, 11, 807-833.

Trompenaars, F. \& Hampden-Turner, C. (1997). Riding the Waves of Culture. Understanding Cultural Diversity in Business. Londan. Nicholas Brealey Publishing.

Ulrich, D. (1997). Human Resource Champions. The next agenda for adding value and delivering results. Harvard Business School Press, Boston.

Ulrich, D. \& Brockbank, W. (2005). The HR value proposition. Boston: Harvard Business School Press, Massachusetts

Venegas,C.B., Thill,K. \& Domnanovich, J. (2017). Strategic Competence in HRM: Evidence from Austria, Czech Republic, Hungary and Slovakia. Journal of Eastern European and Central Asian Research. 4 (2), 307-320.

Whitley, R. (1999). Divergent Capitalismus. The Social Structuring and Change of Business Systems. Oxford. Oxford University Press.

Wood, G.T., Croucher, C., Brewster, C., Collings, G.C. \& Brooks, M. (2009). Varieties of Firm. Complementarity and bounded diversity. 
Journal of Economic Issues, 43, 1, 241-260.

\section{ABOUT THE AUTHORS}

József Poór, email: poorjf@t-online.hu

Dr. József Poór, CMC is a Professor of Management of J. Selye University (Slovakia) and Szent István University (Hungary), where he teaches a variety of management courses. He served as a guest professor at five different U.S. universities and taught fourteen short summer semesters. He was as visiting professor at seventeen universities in Europe, at one university in Latin America and in China, where taught different management subjects. He was senior manager at internationally recognized professional service firms (Mercer, HayGroup, Diebold) and at the International Management Center, Budapest. His scholarly publications have appeared in more than twenty internationally referred journals. He wrote many books in Hungarian, and seven book-chapters in English and one book in Romanian alone or as a co-author.

Dr. Ildikó Éva Kovács is an assistant professor at Szent István University in Gödöllö, currently member of the Management and HR Research Team. She has been working on national and international HRM research projects (Cranet, CEEIRT, Visegrad Fund) and teaching management courses as well. She is one of the authors of numerous publications and monographs on the topic of HRM practices that have appeared in recent years based on the team's research.

Dr. Zsuzsa Karoliny, $\mathrm{PhD}$ is Honorary Professor of the University of Pécs, Faculty of Business and Economics, for a long time being in charge for developing and delivering Human Resource Management modules for a wide variety of courses. Besides teaching at the same University at different positions, she participated in many international faculty exchange programmes and delivered her research activity in both various Hungarian and international research teams and alone as well. The results were published in international and Hungarian professional journals and conference proceedings. She edited and coedited textbooks on Human Resources Management. Author and co-author of several book-chapters published by different Hungarian and International Publishing Houses. The number of her published articles is well above one hundred.

Dr. Renata Machova is a Assistant Professor of Management of J. Selye University (Slovakia), where she teaches a variety of management courses. Her scholarly publications have appeared in more than five internationally referred journals. She wrote several books in Hungarian and in Slovak alone and as co-author. 